\title{
The Pemmican BMJs
}

\section{T D V SWINSCOW}

In the office of the BMF's Editor a candle dripped its wax down over the neck of a sherry bottle that stood on the table. The dense cloud covering London at midday had enveloped the room in dusk, and the absence of gas, electricity, and oil had allowed its temperature to fall to freezing. Members of the editorial staff sat in their overcoats round the flickering candle looking like Van Gogh's "Potato Eaters" planning the next issue (fig). This was the great fuel crisis of 1947 .

To the general public it had become obvious several weeks earlier that a scarcity of fuel was adding to the misfortunes of a severe winter. Lacking atomic energy and North Sea gas we were almost entirely dependent on coal for heating, lighting, and rail transport. Petrol and oil were rationed at low levels and had a much smaller role in the economy than they later attained. The coal mines, though providing a reserved occupation during the war, had nevertheless lost skilled men to the armed Forces, and the miners in 1947 were of a higher average age than is usual. An enormous amount of re-equipment with new machinery was also required, so that production was inadequate from a variety of causes.

The Government through its Minister of Fuel and Power, Mr Emanuel (now Lord, aged 96) Shinwell, assured us that there would be no fuel crisis that winter. But many people felt this to be a statement of probability rather than of ascertained fact-and how right the sceptics were. By the middle of February widespread power cuts and "load shedding" had reduced most homes, factories, and offices to a cold and twilight existence. Crisis or no crisis, the Government had to issue a succession of edicts designed to direct what power was available into the channels where it was most needed for the nation's wellbeing. Naturally many people differed on just where that wellbeing lay. But a moment came when the Government decided that, without any serious impairment of the freedom of the press, the weekly periodicals should make their contribution to fuel saving by suspending publication for the time being. In retrospect it may seem rather a strangely trivial yet contentious sacrifice to order, but, strictly rationed as we still were in almost every walk of domestic and commercial life in the aftermath of the war, a ban of this type seemed more reasonable then. Many other activities were, of course, suspended also, though neither the cold bestowed by Providence nor the deprivations decreed by the Government could reduce life below a certain ebb and flow, as the high birth rate in those years showed.

Looking back now at that fuel crisis and the production during it of the two smallest ever issues of the $B M \mathcal{A}$, we need to have the background in mind-a nation accustomed to hardship, to shortages, to rationing of food, fuel, clothes, and furniture, to standing in queues, and-so much more than today-to getting

Topsham, Exeter, Devon EX3 OAJ

T D V SWINSCOW, MB, MSC, retired deputy editor, BMF Gogh, Amsterdam.) government permission before taking action. But the last in particular was not something that ever appealed to the newly $\frac{\bar{m}}{\triangle}$ appointed Editor, Dr Hugh Clegg. Though strictly speaking $\mathscr{\perp}$ "newly appointed," Dr Clegg had been on the editorial staff for $\cong$ about 16 years and for most of the war had been required largely to edit the journal owing to the ill health of the aging editor, $\mathrm{Dr}$. Gerald Horner. The latter had retired at the end of 1946 , so $\mathrm{Dr} \vec{\omega}$ Clegg had actually occupied the editorial chair only since the $\stackrel{\circ}{\circ}$ beginning of 1947, a few weeks before the fuel shortage reached $\frac{5}{3}$ its crisis. As I had been appointed to the editorial staff only six months previously my role in these events was that of a humble $\propto$ assistant.

When the Government's decree went forth that weekly on periodicals were to suspend publication, we on the $B M F$ staff, $\stackrel{\circ}{-}$ with that hubris that is such a constant source of annoyance to non-medical people, decided that medicine was too important $\mathscr{}$

"The Potato Eaters" by Vincent van Gogh. (Courtesy of the National Museum Vincent van $N$

to the community to have its most cherished journal (as we $\tilde{\circ}$ regarded it) swept from the scene for an unforeseeable number $\mathrm{N}_{\mathrm{J}}$ of weeks. Nor did we contemplate infringing the law in letter or: spirit by using fuel in its production. But why not produce ace journal without the use of fuel ? And what exactly was the nature $\mathbb{D}$ of the ban that lay on weekly periodicals? This will be discussed $\stackrel{\mathscr{N}}{+}$ further below, but at the present stage $\mathrm{Dr}$ Clegg made a number $\underset{T}{T}$ of inquiries, the responses to which convinced him of two things: $\frac{\text { Dे }}{\bar{D}}$

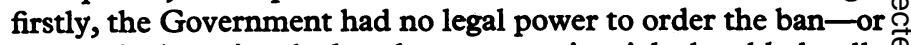
at least had not invoked such powers as it might be able legally $\mathbb{\perp}$ to command; secondly, that even if we used no fuel at all the mere publication of the $B M \mathcal{F}$ would incur the displeasure of a $\delta$ body called the Periodical Trade Press and Weekly Newspapero Proprietors' Association (PPA), which was said to have entered into an agreement with the Government to observe the ban. It is worth noting here that the $B M F$ was not a member of the PPA, its application to join having been rejected in 1938 . 
Thus, determined not to allow the $B M \mathcal{F}$ to vanish needlessly, Hugh Clegg called an editorial meeting round the candle in his room, and we began work on the issue dated 22 February 1947. Meanwhile he had obtained assurances from the Secretary that his staff would be available for cyclostyling the $B M \mathcal{F}$ and dispatching it without the use of any fuel except candles. To make this possible the Editor decided that the whole issue should be on a single sheet of foolscap paper, cyclostyled on both sides. We thereupon reduced news items to a line or so, letters to "Points," obituaries to name, age, and a sentence, and advertisements for hospital appointments (one of our most essential services) to much abbreviated but what we hoped were unambiguous announcements. Finally, a leading article drew attention to the fact that coal is a source of medicine as well as of power, for its constituents had given us carbolic acid, dyestuffs from which the sulphonamides had been synthesised, synthetic antimalarials, aspirin, and stilboestrol. The text of the whole issue was then carefully cut on a series of stencils, from these the cyclostyled sheets were printed, and some 62000 copies were put into envelopes, addressed, and dispatched. The journal staff were grateful to the Secretariat for running this operation so willingly and smoothly.

As the fuel crisis continued, it became apparent that another issue of the $B M F$ would be needed on the same lines. So for 1 March we prepared the second "pemmican" issue, as they were called-from the American Indian word for a cake of dried and pounded meat mixed with currants for travellers in the Arctic $(O E D)$. This time the leader was on "freedom to print." The theme touched on here was that "the freedom of the press is not a privilege of the newspaper but a fundamental liberty of the subject." Once again willing hands in the BMA Secretariat cyclostyled and dispatched the entire issue without the use of fuel.

Thereafter the fuel crisis subsided, the weather improved, our feet warmed up, our breath was less cloudy on the air, and a shoal of congratulatory letters flooded in. A selection could be published in succeeding issues of the journal in its customary form once again. Among those letters was one from Sir Ernest Graham-Little, ${ }^{1}$ a Tory MP with a medical degree, who exposed the confusion in Parliament and outside over the nature of the ban on publication. As he pointed out, the Prime Minister (Clement Attlee) speaking in the Commons and Lord Chorley speaking for the Government in the Lords had put out rather different versions of the Government's actions. Furthermore, according to the Prime Minister it was done by agreement with the PPA, ${ }^{2}$ but Graham-Little said that the instruction was in fact issued "three days before any consultation with the PPA was attempted." That the Government acted, and then tried to justify its actions, in a casually high-handed manner seems plain. Graham-Little also suggested that it might have been convenient to ministers to silence the medical journals during negotiations in progress on the projected national health service, and he observed that, "The possibility of such back-stage ministerial intrigues lends a sinister significance to this new encroachment on our liberties." This, however, was going a bit far: experienced politicians would surely not have intrigued so ineptly.

No doubt the episode was a small crackle in a sky lurid with the fireworks of a world trying to rebuild itself from the ruins of war, but to me at least the Editor's action on that occasion has always seemed to be as percipient as it was resolute. Democratic parliamentary rule had been established at Westminster again after its virtual suspension for six years. Nearly everyone accepted the continued need for rationing at that time, but the feeling was also strong that the Government must govern under the law and that a vigilant press was needed to ensure that it did so. We had spent over five years fighting against murderously efficient tyrannies, and for part of that time we had perforce been the admiring allies of a tyranny as deadly as those we fought. Western parliamentary democracy was-and perhaps still is-a frail vessel on a stormy sea, and the abuse of its powers by our own Government seemed to us on the $B M F$ to contain a hint of all that we most detested. A reader today who thinks that must be an exaggerated view makes his judgment from a different perspective, for the most obvious threat to parliamentary democracy in this country now comes from those trade unions and other bodies outside Parliament who attempt to destroy governments by extraparliamentary means. But in 1947 a vast web of wartime controls still persisted, on the whole with the nation's consent, and the slightest misuse of them by the Government needed to be challenged.

Perhaps I may end on a personal note. My wife and I sometimes recall the great fuel crisis with wry amusement, for between the production of the two pemmican issues of the $B M F$ she gave birth to our first baby.

\section{References}

1 Graham-Little E. The pemmican BMf. Br Med f 1947 ;i:349.

${ }^{2}$ Medical Notes in Parliament. Br Med $\mathscr{f} 1947 ; \mathrm{i}: 317$.

(Accepted 2 fuly 1980)

\section{As others see us}
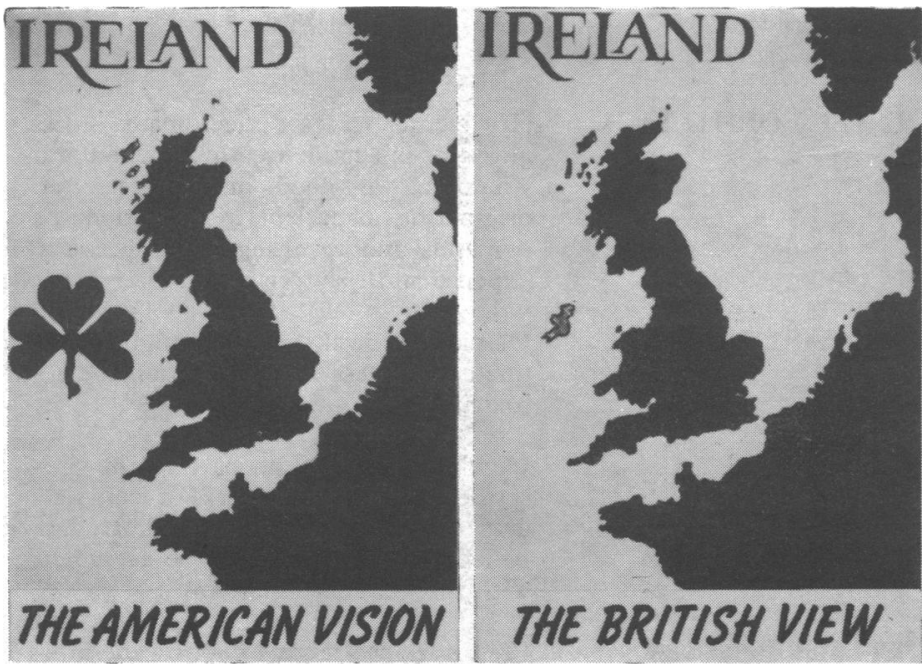
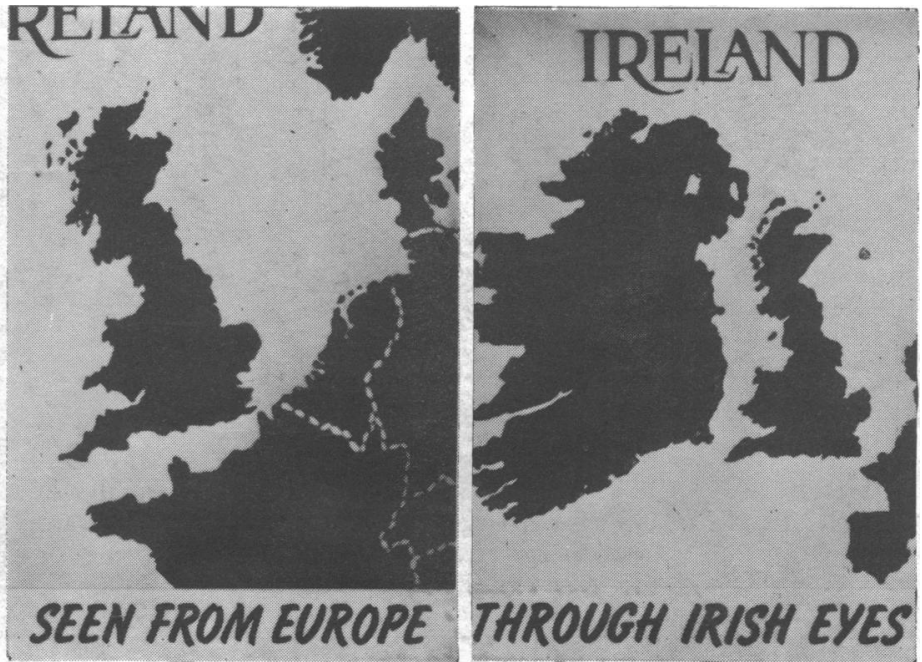